\title{
A $\beta$ (25-35)-Induced Memory Impairment, Axonal Atrophy, and Synaptic Loss are Ameliorated by MI, A Metabolite of Protopanaxadiol-Type Saponins
}

\author{
Chihiro Tohda', Noriaki Matsumoto', Kun Zou ', Meselhy R Meselhy' and Katsuko Komatsu*,I,2 \\ 'Research Center for Ethnomedicines, Institute of Natural Medicine, Toyama Medical and Pharmaceutical University, Toyama, Japan; ${ }^{2} 2$ I st \\ Century COE Program, Toyama Medical and Pharmaceutical University, Toyama, Japan
}

\begin{abstract}
We previously screened neurite outgrowth activities of several Ginseng drugs in human neuroblastoma, and demonstrated that protopanaxadiol (ppd)-type saponins were active constituents. Since ppd-type saponins are known to be completely metabolized to 20O- $\beta$-D-glucopyranosyl-20(S)-protopanaxadiol (MI) by intestinal bacteria when taken orally, $\mathrm{MI}$ and ginsenoside Rb।, as a representative of ppd-type saponins, were examined for cognitive disorder. In a mouse model of Alzheimer's disease (AD) by A $\beta(25-35)$ i.c.v. injection, impaired spatial memory was recovered by p.o. administration of ginsenoside $\mathrm{Rb}_{1}$ or Ml. Although the expression levels of phosphorylated NF-H and synaptophysin were reduced in the cerebral cortex and the hippocampus of $A \beta(25-35)$-injected mice, their levels in ginsenoside $\mathrm{Rb}_{1}$ - and $\mathrm{MI}$-treated mice were almost completely recovered up to control levels. Potencies of the effects were not different between ginsenoside $\mathrm{Rb}$, and $\mathrm{MI}$ when given orally, suggesting that most of the ginsenoside Rb, may be metabolized to MI, and $\mathrm{MI}$ is an active principal of ppd-type saponins for the memory improvement. In cultured rat cortical neurons, MI showed extension activity of axons, but not dendrites. The axon-specific outgrowth was seen even when neuritic atrophy had already progressed in response to administration of $\mathrm{A} \beta(25-35)$ as well as in the normal condition. These results suggest that MI has axonal extension activity in degenerated neurons, and improve memory disorder and synaptic loss induced by A $\beta(25-35)$. MI was shown to be effective in vitro and in vivo, indicating that Ginseng drugs containing ppd-type saponins may reactivate neuronal function in AD by p.o. administration. Neuropsychopharmacology (2004) 29, 860-868, advance online publication, 10 March 2004; doi: I 0. I 038/sj.npp. 1300388
\end{abstract}

Keywords: Alzheimer's disease; ginseng; MI; ginsenoside Rb,; axonal atrophy; synaptic loss

\section{INTRODUCTION}

Ginseng, the root of Panax ginseng, is widely used as a tonic medicine throughout the world, and has also been found to be efficacious in the treatment of amnesia. In addition, significant improvement in learning and memory has been observed in brain-damaged rats (Zhao and McDaniel, 1998; Zhong et al, 2000) and aged rats (Zhong et al, 2000) after oral administration of ginseng powder, and the major ginseng saponins, ginsenoside $\mathrm{Rb}_{1}$ and $\mathrm{Rg}_{1}$, are known to improve spatial learning in normal mice (Mook-Jung et al, 2001). With respect to their effects on neuronal cells, it has been shown that neurite outgrowth of rat cultured cerebral

\footnotetext{
*Correspondence: Dr Katsuko Komatsu, Research Center for Ethnomedicines, Institute of Natural Medicine, Toyama Medical and Pharmaceutical University, 2630 Sugitani, Toyama 930-0194, Japan, Tel: +8I 76434 7645, Fax: + 8176434 5064,

E-mail: katsukok@ms.toyama-mpu.ac.jp

Received 22 August 2003; revised I0 November 2003; accepted I। December 2003

Online publication: 18 December 2003 at http://www.acnp.org/ citations/Npp | 2 180303383/default.pdf
}

cortical neurons is enhanced by crude ginseng saponins (Sugaya et al, 1988), and that ginsenoside $\mathrm{Rb}_{1}$ potentiates the nerve growth factor (NGF)-mediated neurite outgrowth of chick dorsal root ganglia (Saito et al, 1977; Nishiyama et al, 1994). We have previously studied the neurite outgrowth activity of methanol extracts from seven kinds of Ginseng drugs and 19 constituents isolated from YeSanchi (rhizome of Panax vietnamensis HA et GRUSHV. var. fuscidiscus K.Komatsu, S. Zhu \& S.Q. Cai) and Kouzichi (rhizome of $P$. japonicus C.A.Meyer var. major C.Y. Wu et Feng) in human neuroblastoma SK-N-SH cells, and found that protopanaxadiol (ppd)-type saponins (ginsenoside $R b_{1}$, ginsenoside $R b_{3}$, notoginsenoside $R_{4}$, and notoginsenoside $\mathrm{Fa}$ ) were the active compounds (Tohda et al, 2002). As the outgrowth and maturation of neurites are basic steps for synaptogenesis, the ppd-type saponins could possibly activate and recover the function of degenerated brain.

When taken orally, ppd-type saponins are mostly metabolized by intestinal bacteria to ppd monoglucoside, 20-O- $\beta$-D-glucopyranosyl-20(S)-protopanaxadiol (M1) (Odani et al, 1983; Tawab et al, 2003). Considering that 
Ginseng drugs are generally taken orally, a metabolite of ppd-type saponins, M1 must be investigated to determine the real active constituent of Ginseng responsible for its major effects.

Regardless of type, dementia is induced by neuronal degeneration. The presently available drugs for dementia such as acetylcholinesterase inhibitors are efficacious in the temporary treatment of memory dysfunction, but do not prevent or reverse the underlying neurodegeneration (Ogura et al, 2000). The essential requirement for a truly effective antidementia drug would be reorganizing synaptic connections after the progression of neuronal degeneration. Therefore, the present experiments were conducted to determine whether treatment with ginsenoside $R b_{1}$, as a representative of ppd-type saponins, and their metabolite M1 can result in recovery from memory disorder, axonal atrophy, and synaptic loss induced by the active fragment of the amyloid $\beta$ peptide $(\mathrm{A} \beta(25-35))$.

\section{METHODS}

\section{Materials}

Ginsenoside $\mathrm{Rb}_{1}$ was isolated from Ye-Sanchi as described previously (Tohda et al, 2002). Voucher specimens of Ye-Sanchi were deposited in the Museum of Materia Medica, Research Center for Ethnomedicines of our University.

M1 was enzymatically prepared from ginsenoside $R b_{1}$. Ginsenoside $\mathrm{Rb}_{1}(260 \mathrm{mg}$ ) was dissolved in $15 \mathrm{ml}$ of $0.2 \mathrm{M}$ sodium dihydrogenphosphate buffer ( $\mathrm{pH} 4.0$ ), to which $3 \mathrm{ml}$ ethanol, $250 \mathrm{mg}$ of naringinase (Sigma-Aldrich, St Louis, MO, USA), and $2 \mathrm{ml}$ toluene were gradually added. After incubation at $40^{\circ} \mathrm{C}$ for 4 days, the mixture was extracted three times with $100 \mathrm{ml}$ ether and was dehydrated by filtration over magnesium sulfate. After concentration under reduced pressure, the product was purified by column chromatography over silica gel to give $70 \mathrm{mg}$ of M1. The chemical structure of M1 was identified as follows: a white amorphous powder, ${ }^{1} \mathrm{H}-\mathrm{NMR}$ (pyridine-d5): signals for the aglycone moiety at $\delta 0.78-2.61,3.41(1 \mathrm{H}, \mathrm{m}, \mathrm{H}-3)$, and $5.24(1 \mathrm{H}, \mathrm{t}$ like, $\mathrm{H}-24)$, signals for a glycosyl moiety at $\delta 3.84-4.45(6 \mathrm{H}, \mathrm{m}$, including a proton signal for $\mathrm{H}-12$ of the aglycone) and $5.15(1 \mathrm{H}, \mathrm{d}, J=7.5 \mathrm{~Hz}, \mathrm{H}-1)$.

\section{Procedures}

Animals and drug treatments. Male ddY mice (6 weeks old, SLC, Shizuoka, Japan) were housed five or six per cage with free access to food and water, and were kept in a constant environment $\left(22 \pm 2{ }^{\circ} \mathrm{C}, 50 \pm 5 \%\right.$ humidity, $12-\mathrm{h}$ light cycle starting at 7000). The animals were handled in accordance with the Guide for Animal Experiments, Toyama Medical and Pharmaceutical University. A $\beta(25-$ 35) was dissolved in sterile distilled saline at a concentration of $1 \mathrm{mM}$, and incubated at $37^{\circ} \mathrm{C}$ for 4 days to obtain the aggregated form. Under anesthetization, peptides $(5 \mu \mathrm{l}=5 \mathrm{nmol})$ or vehicle (saline) were injected into the right ventricle, with stereotaxic coordinates from the bregma being, in $\mathrm{mm}, \mathrm{A}-0.22, \mathrm{~L}-1.0$, and $\mathrm{V} 2.5$. At 7 days after the i.c.v. injection of $A \beta(25-35)$, ginsenoside $\mathrm{Rb}_{1}$ $(10 \mu \mathrm{mol} / \mathrm{kg})$, M1 $(10 \mu \mathrm{mol} / \mathrm{kg})$, donepezil hydrochloride (DNP, $0.5 \mathrm{mg} / \mathrm{kg}$, Eisai, Tokyo, Japan), or vehicle (tap water) was administered orally once daily for 14 days.
Water maze test. White-colored water was poured into a circular pool (diameter, $120 \mathrm{~cm}$; height, $28 \mathrm{~cm}$ ), and a white platform (diameter, $8.3 \mathrm{~cm}$ ) was placed $1.5 \mathrm{~cm}$ below the water level in the middle of a fixed quadrant. The water temperature was adjusted to $25^{\circ} \mathrm{C}$. Memory-acquisition trials (training) were performed four times daily for 7 days to reach a steady state of escape latency. At $1 \mathrm{~h}$ after p.o. administration of the drugs, the mice were allowed to swim freely for $60 \mathrm{~s}$ and were left for an additional $30 \mathrm{~s}$ on the platform. The intertrial interval during four trials was 75 min. Start positions, set at each limit between quadrants, were randomly selected for each animal. Mice failing to find the platform were placed on the platform manually.

Memory-retention tests were performed 6 days after the last training session, that is, 6 days after discontinuation of p.o. administration of the drugs. The platform was removed, and each mouse was allowed a free 60-s swim. The number of crossings over a point where the platform had been was counted by replay using a video recorder.

Locomotor activity. Measurement of the locomotor activity was carried out 2 days after the retention test. Mice were placed in a wheel cage (Model SW-20, Toyo Sangyo, Toyama, Japan), and the number of revolutions was counted for $20 \mathrm{~min}$.

Primary culture. Embryos were removed from pregnant Sprague-Dawley rats (Japan SLC, Shizuoka, Japan) at 18 days of gestation (E18). The animals were handled in accordance with the Guide for Animal Experiments, Toyama Medical and Pharmaceutical University. The cortices were dissected, and the dura mater was removed. The cells were chopped, dissociated, and plated onto fourwell chamber slides (Falcon) at a density of $4.50 \times 10^{4}$ cells/ $\mathrm{cm}^{2}$ (Figure 4), $1.00 \times 10^{5}$ cells $/ \mathrm{cm}^{2}$ (Figure 5), or $7.50 \times 10^{4}$ cells $/ \mathrm{cm}^{2}$ (Figure 6$)$ coated with poly-D-lysine $(5 \mu \mathrm{g} / \mathrm{ml})$, and grown at $37^{\circ} \mathrm{C}$ in a humidified atmosphere with $10 \% \mathrm{CO}_{2}$. $\mathrm{A} \beta(25-35)$ (Sigma) was dissolved in sterilized $\mathrm{dH}_{2} \mathrm{O}$ and incubated at $37^{\circ} \mathrm{C}$ for 4 days to be aggregated. As a positive control, mouse $\beta$-NGF (Austral Biologicals, San Ramon, USA) was used.

Immunocytochemistry. At 3 days after the retention test, the mice were killed by decapitation. The brains were quickly removed from the skull, kept in powdered dry ice, and were subsequently stored at $-80^{\circ} \mathrm{C}$. In all, $12-\mu \mathrm{m}$ coronal sections were cut in a cryostat (CM3050S, Leica, Heidelberg, Germany) at $-20^{\circ} \mathrm{C}$, thaw-mounted onto gelatin-coated slides, and stored at $-20^{\circ} \mathrm{C}$ until use. Slices were fixed with $4 \%$ paraformaldehyde in phosphatebuffered saline (PBS) for $1 \mathrm{~h}$, and stained with a monoclonal antibody to phosphorylated NF-H (dilution $1: 1000$, Sternberger Monoclonals Inc., Lutherville, MD, USA), a monoclonal antibody to synaptophysin (dilution 1:500, Chemicon, Temecula, CA, USA) as a synaptic marker or polyclonal antibody to MAP2 (dilution 1:1000, Chemicon, Temecula, CA, USA) as a dendrite marker. PBS containing $0.3 \%$ Triton-X, an antibody, and $1 \%$ normal goat serum were added to the fixed slices. After incubation for $2 \mathrm{~h}$ at room temperature, slices were rinsed with PBS containing $0.2 \%$ Triton-X containing. Using Alexa Fluor 488-conjugated goat anti-mouse IgG (dilution 1:100, Molecular 
Probes, Eugene, OR, USA) as the secondary antibody, slices were incubated for $2 \mathrm{~h}$ at room temperature. Primary cultured cortical neurons were fixed and immunostained with monoclonal antibody to phosphorylated neurofilament-H (NF-H) (dilution 1:1000, Sternberger Monoclonals Inc.) as an axonal marker or monoclonal antibody to MAP2 (MAP2a and 2b; dilution 1:200, Chemicon, Temecula, CA, USA) as a dendrite marker. Alexa Fluor 488-conjugated goat anti-mouse IgG (dilution 1:100, Molecular Probes, Eugene, OR, USA) was used as a second antibody. The slides were mounted with Aqua Poly Mount (Polysciences, Warrington, $\mathrm{PA}, \mathrm{USA})$ and viewed with a fluorescence microscope (AX80, Olympus, Tokyo, Japan).

Image analysis of immunostained neurons. The size of each captured image was $450 \times 600 \mu \mathrm{m}$, and four images were captured per treatment. For brain slices, the average fluorescence intensities in six areas of $30 \times 30 \mu \mathrm{m}$ per image were measured. For cultured neurons, the lengths of neurites positive for phosphorylated NF-H or MAP2 were measured by an image analyzer (Scion Image, Scion, Frederick, MD, USA) for each cell, and the measurements were performed in 30 cells per treatment.

\section{Statistical Analysis}

Statistical comparisons were made by the Student's $t$-test; one-way analysis of variance (one-way ANOVA) or two-way repeated measure analysis of variance (two-way RM ANOVA) was carried out, followed by Dunnett's post hoc test. Values of $p<0.05$ were considered significant. The means of the data are presented together with SEM.

\section{RESULTS}

Effects of Ginsenoside $R b_{1}$ and $M 1$ on the Impairment of Spatial Memory

The structures of ginsenoside $\mathrm{Rb}_{1}$ and metabolite $\mathrm{M} 1$ are shown in Figure 1. Mice were trained in the water maze for 7 days starting at 14 days after the i.c.v. administration of $\mathrm{A} \beta(25-35)$ (Figure 2a). Mice became more efficient at finding the platform on successive trials. The main effect for day was statistically significant $(F(6,24)=67.621$, $p<0.0001)$. The main effect for drug was also statistically significant $(\mathrm{F}(4,40)=3.003, p=0.0294)$. Two-way RM

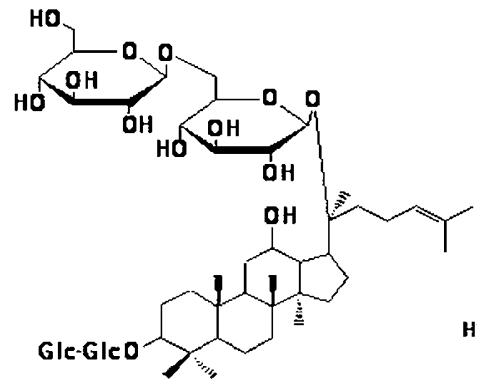

Ginsenoside Rb

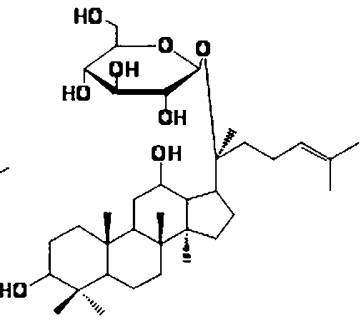

M1
Figure I Structures of ginsenoside $\mathrm{Rb}_{\mathrm{I}}$ and $\mathrm{MI}$.
ANOVA revealed a significant increase in escape latency to find the platform in the $\mathrm{A} \beta(25-35)$-injected group compared with the saline-injected group $(\mathrm{F}(1,16)=5.961$,
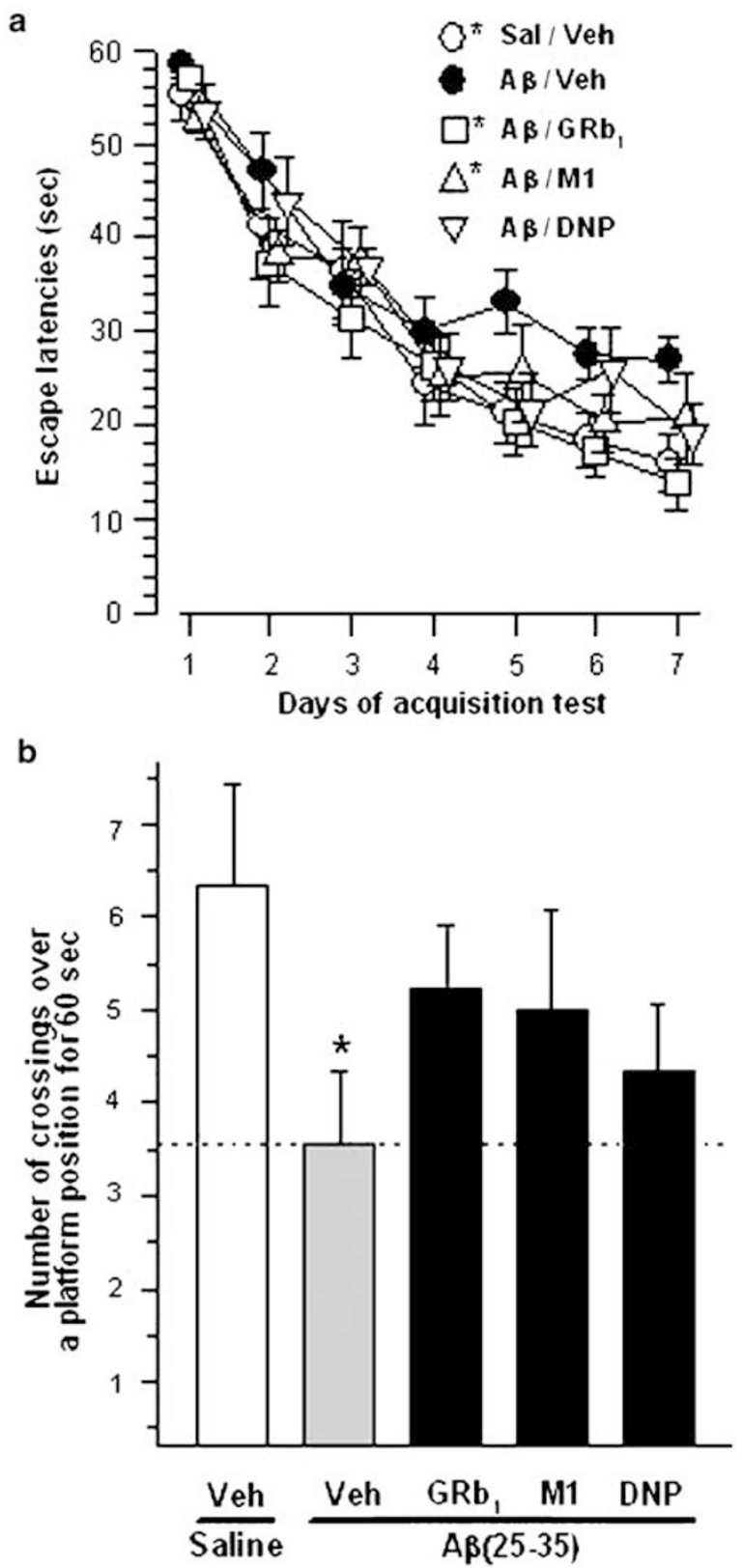

Figure 2 Effects of ginsenoside $\mathrm{Rb}$, and $\mathrm{MI}$ on the impairment of spatial memory induced by $A \beta(25-35)$ injection. (a) Escape latencies per group of four trials were tested in a Morris water maze over 7 days. Vehicle was p.o. administered to saline-i.c.v.-injected (open circles) mice. To A $\beta(25-35)$ i.c.v.-injected mice, vehicle (closed circles), ginsenoside $\mathrm{Rb}$, $(10 \mu \mathrm{mol} / \mathrm{kg}$, open squares), $\mathrm{MI}$ ( $10 \mu \mathrm{mol} / \mathrm{kg}$, open triangles), or donepezil $(0.5 \mathrm{mg} / \mathrm{kg}$, open inverted triangles) was p.o. administered for 14 days. (b) The number of crossings over a position where a platform had been was measured for $60 \mathrm{~s}$ at 6 days after the last acquisition test. That time was also 6 days after discontinuance of drug treatment. Vehicle was p.o. administered to salinei.c.v.-injected (open column) mice. To $A \beta(25-35)$-i.c.v.-injected mice, vehicle (Veh, gray column), ginsenoside $R b_{1}\left(G R b_{1}\right), M I$, or donepezil (DNP) was p.o. administered. Values represent the means and SEM of nine mice. ${ }^{*} p<0.05$ when compared with the $A \beta(25-35)$ plus vehicle-treated group in the acquisition test. $* p<0.05$ when compared with the saline plus vehicle-treated group in the retention test. 
$p=0.0266)$, and significant decreases in escape latencies in groups to which ginsenoside $\mathrm{Rb}_{1} \quad(10 \mu \mathrm{mol} / \mathrm{kg})$ $(\mathrm{F}(1,16)=22.591, \quad p=0.0002) \quad$ and $\quad \mathrm{M} 1 \quad(10 \mu \mathrm{mol} / \mathrm{kg})$ $(\mathrm{F}(1,16)=4.892, p=0.0419)$ were p.o.-administered com-
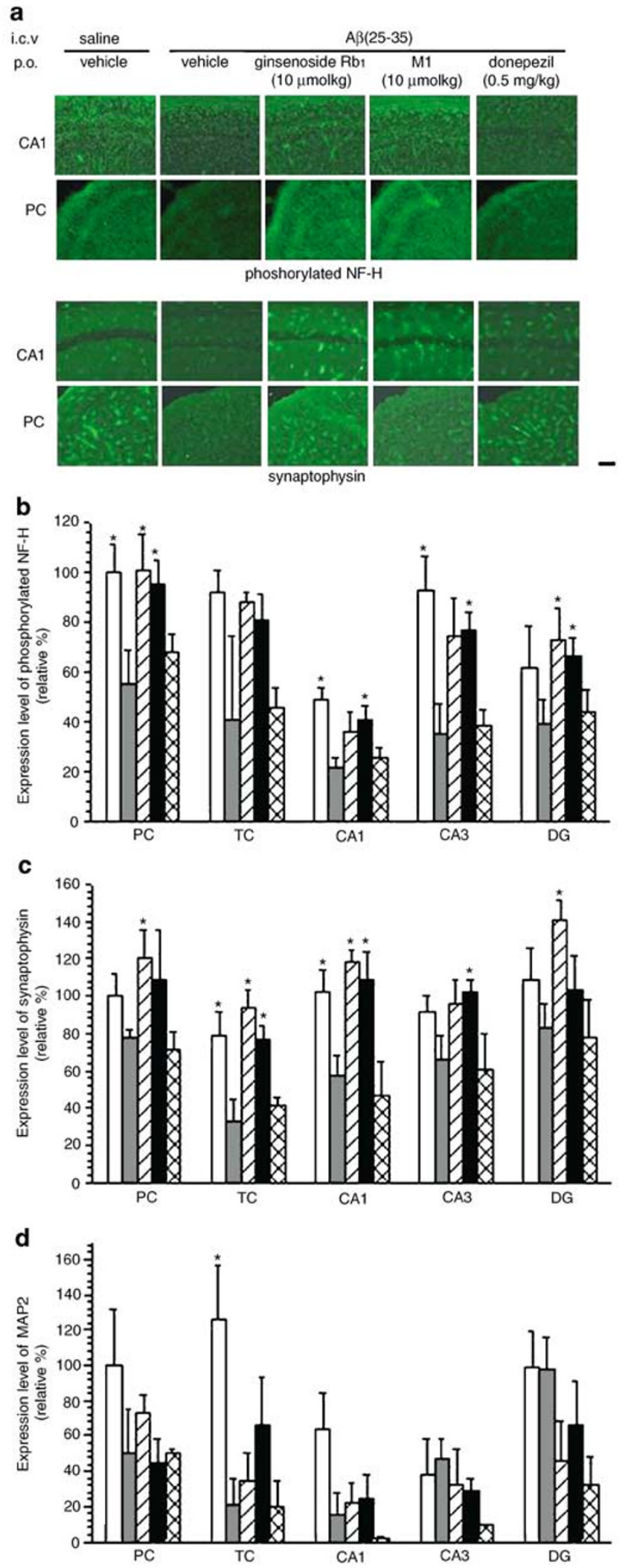

pared with the vehicle-administered group. The donepeziladministered group $(0.5 \mathrm{mg} / \mathrm{kg}$, p.o.) showed no significant shortening of the escape latency $(\mathrm{F}(1,16)=3.885$, $p=0.0663$ ).

In the retention test (Figure $2 \mathrm{~b}$ ), the number of crossings over a platform position was significantly decreased in the A $\beta(25-35)$-injected group compared with that in the salineinjected group. The crossing numbers were recovered by treatment with ginsenoside $\mathrm{Rb}_{1}$ and $\mathrm{M} 1$, although the recovery was not significant. Treatment with donepezil showed the smallest effect on the retention test. All mice showed normal swimming performance and constant increases in body weight. Locomotor activity did not differ among groups.

After the retention test, the expression levels of phosphorylated NF-H (axonal marker), synaptophysin (synaptic marker), and MAP2 (dendritic marker) were measured in mouse brains. We observed two cortical areas (parietal cortex and temporal cortex) and three hippocampal areas (CA1, CA3, and the dentate gyrus), as it is known that synaptic loss occurs primarily in the cerebral cortex and hippocampus in Alzheimer's disease (AD) patients (DeKosky and Scheff, 1990; Heinonen et al, 1995) and in AD model mice (Games et al, 1995). The phosphorylated NF-H and synaptophysin were remarkably reduced in the brain of an $\mathrm{A} \beta(25-35)$-injected mouse (Figure 3a). However, their expressions were kept to control level in mice treated by ginsenoside $\mathrm{Rb}_{1}$ or M1. Quantified data also indicated the following. The phosphorylated NF-H levels were remarkably reduced in these five areas of the brain in $\mathrm{A} \beta(25-35)$ injected compared with saline-injected mice (Figure $3 \mathrm{~b}$ ). Significant decreases were seen in the parietal cortex, CA1, and CA3. However, the expression levels of phosphorylated NF-H were nearly equal to those of the control in ginsenoside $\mathrm{Rb}_{1}$ - and M1-treated mice. Donepezil treatment had no effect on the levels of phosphorylated NF-H. The synaptophysin levels were also reduced in those five areas of the brain in $\mathrm{A} \beta(25-35)$-injected compared with salineinjected mice (Figure 3c). Significant decreases were seen in the temporal cortex and CA1. In all areas, the synaptophysin levels were almost equal to or higher than control levels in ginsenoside $\mathrm{Rb}_{1}$ - and M1-treated mice. Donepezil treatment had no effect on the synaptophysin levels. The MAP2 levels were also reduced in the cerebral cortex and CA1 of the brain in $\mathrm{A} \beta(25-35)$-injected compared with saline-injected mice (Figure 3d). Significant decreases were

Figure 3 Effects of ginsenoside $\mathrm{Rb}$, and $\mathrm{MI}$ on the axonal atrophy and synaptic loss induced by $A \beta(25-35)$ injection. The expressions of phosphorylated NF-H and synaptophysin after memory tests in CAI and the parietal cortex are shown in green color (a). Scale $=100 \mu \mathrm{m}$. Expression levels of phosphorylated NF-H (b), synaptophysin (c), and MAP2 (d) in brain slices were quantified. Vehicle was p.o. administered to saline-i.c.v.-injected mice (open columns). To $A \beta(25-35)$-i.c.v.-injected mice, vehicle (gray columns), ginsenoside $\mathrm{Rb}$ । $(10 \mu \mathrm{mol} / \mathrm{kg}$, hatched columns), $\mathrm{MI}$ ( $10 \mu \mathrm{mol} / \mathrm{kg}$, closed columns), or donepezil $(0.5 \mathrm{mg} / \mathrm{kg}$, cross-hatched columns) was p.o. administered for 14 days. The parietal cortex (PC), the temporal cortex (TC), hippocampal CAI and CA3, and the dentate gyrus (DG) were observed. The fluorescence intensities of six areas in each slice were measured. Values represent the means and SEM of three mice. ${ }^{*} p<0.05$ when compared with the $A \beta(25-35)$ plus vehicletreated group. 
seen in the temporal cortex. However, these decreases in expression levels of MAP2 were not recovered clearly by ginsenoside $\mathrm{Rb}_{1}, \mathrm{M} 1$, or donepezil. Although treatment with M1 tended to increase the MAP2 level in the temporal cortex, the effect was weak.

The neuronal densities were investigated by Nissl staining in serial slices, and no differences in density were observed among all groups in any brain areas (data not shown).

\section{Effect of M1 on Neurite Extension in Normal Cortical Neurons}

Animal studies in Figures 2 and 3 indicated that ginsenoside $\mathrm{Rb}_{1}$ and $\mathrm{M} 1$ had almost the same potencies for the memory improvement, decline of axons, and synaptic loss, when taken orally. These findings suggested that orally administered ginsenoside $R b_{1}$ is metabolized to $M 1$, which is an active principal for recovery from $\mathrm{A} \beta(25-35)$-induced neuronal dysfunction. Therefore, we next investigated the effects of M1 on atrophy of axons and dendrites in cultured cortical neurons. First, the effect of M1 on neurite extension was tested in normal cortical neurons. Rat cortical neurons were treated by M1 at day 1 . At day 7, cells were fixed and immunostained with an antibody of phosphorylated NF-H (axonal marker) or MAP2 (dendritic marker). Treatment with $0.01-1 \mu \mathrm{M}$ M1 significantly enhanced the length of phosphorylated NF-H-positive neurites compared with vehicle-treated cells (Figure 4a). In contrast, the length of MAP2-positive neurites was not increased by the treatment with M1 (Figure 4b). NGF $(100 \mathrm{ng} / \mathrm{ml})$ significantly enhanced the lengths of phosphorylated NF-H- and MAP2positive neurites.

\section{Effect of M1 on $A \beta(25-35)$-Induced Neurite Atrophy}

Drugs and $10 \mu \mathrm{M} \mathrm{A} \beta(25-35)$ were simultaneously applied to cortical neurons at day 1 . After 4 days, immunostaining was carried out. Both phosphorylated NF-H- and MAP2-positive neurites were significantly shortened by $\mathrm{A} \beta(25-35)$ treatment compared with control (Figures $5 \mathrm{a}$ and $\mathrm{b}$ ). Treatment with $0.01-10 \mu \mathrm{M}$ M1 (maximal effect at $0.1 \mu \mathrm{M}$, to $111.4 \%$ of control) resulted in a significant recovery of the length of phosphorylated NF-H-positive neurites (Figure 5a). MAP2positive neurites were not extended by the treatment with M1 (Figure $5 b)$. NGF (100 ng/ml) significantly enhanced the lengths of phosphorylated NF-H-positive (95.7\% of control) and MAP2-positive neurites (65.2\% of control).

To investigate the $\mathrm{A} \beta(25-35)$-induced damage of the neuronal network and the reconstructive activity of drugs used to treat the impaired networks, $10 \mu \mathrm{M} \mathrm{A} \beta(25-35)$ was added to cortical neurons at day 7 , and 3 days later, the medium was replaced by a new one including drugs. Although the cortical neurons became connected to each other during the 7-day culture, some of the connections were lost at 3 days after $\mathrm{A} \beta(25-35)$ treatment (Figure 6a). At 4 days after drug administration, cells were immunostained. Both phosphorylated NF-H-positive (Figures $6 \mathrm{~b}$ and $\mathrm{c}$ ) and MAP2-positive (Figure 6d) neurites were significantly shortened by $\mathrm{A} \beta(25-35)$ treatment. Treatment with $0.01 \mu \mathrm{M}$ M1 (to $78.5 \%$ of control) significantly increased recovery of the length of phosphorylated NF-H-positive neurites (Figure 6c). MAP2-positive neurites were not
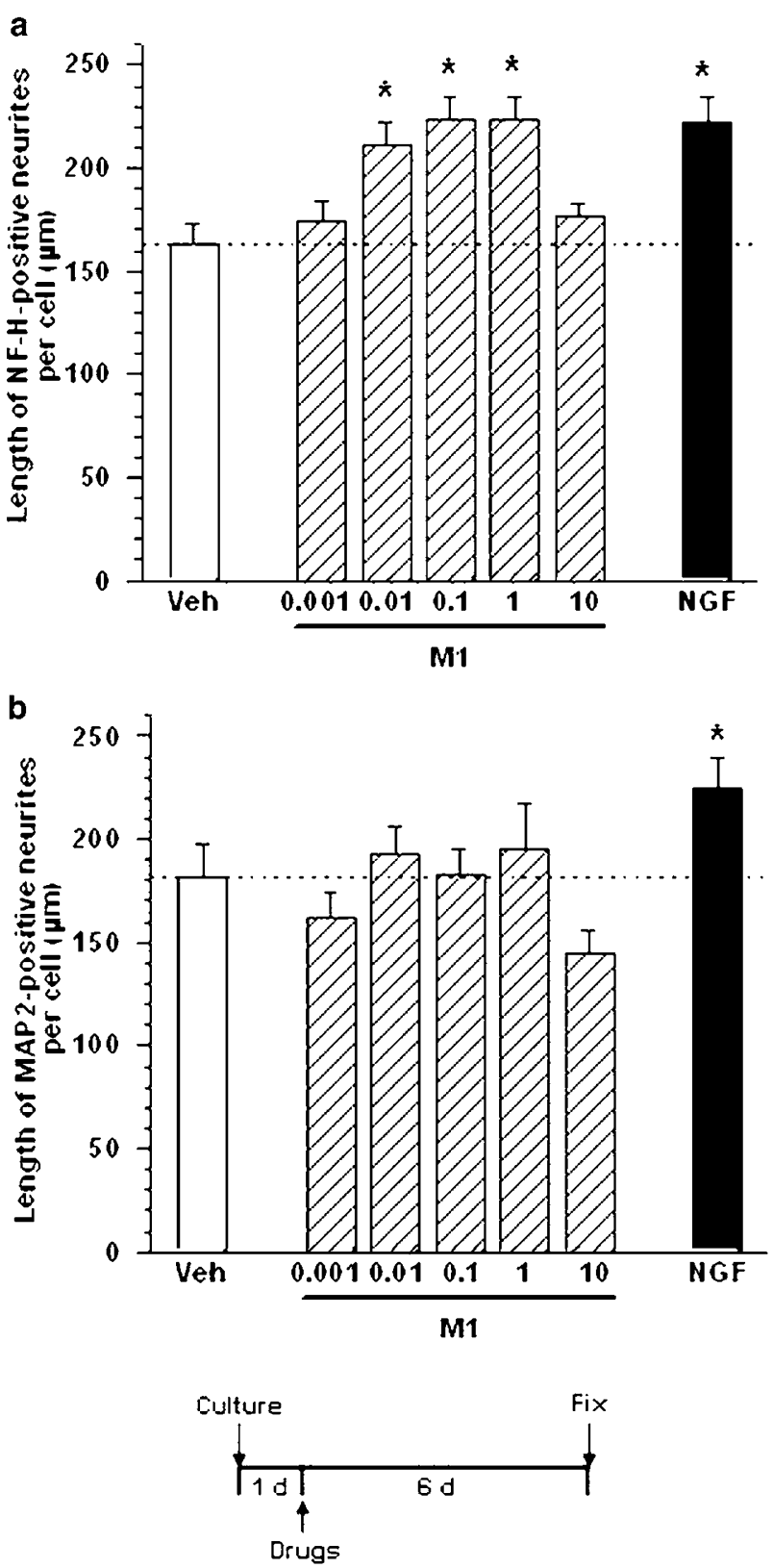

Figure 4 Effect of $\mathrm{MI}$ on extension of axons and dendrites. MI (0.00I$10 \mu \mathrm{M})$, NGF (I00 ng/ml), or vehicle (Veh, DMSO) was added to rat cortical neurons I day after the start of the culture period. After 6 days, cells were fixed and immunostained for phosphorylated NF-H (a) and MAP2 (b). The lengths of neurites positive for phosphorylated NF-H or MAP2 per cell were measured. Values represent the means and SEM of 30 neurons. $*$ $p<0.05$ when compared with Veh.

extended by the treatment with M1 (Figure 6d). NGF $(100 \mathrm{ng} / \mathrm{ml})$ significantly enhanced the lengths of phosphorylated NF-H-positive (to $82.0 \%$ of control) and MAP2positive neurites (to $95.3 \%$ of control).

\section{DISCUSSION}

We have found for the first time in the present study that the treatment with $M 1$, a metabolite of ginsenoside $R b_{1}$, results in the recovery of impaired learning and memory in 

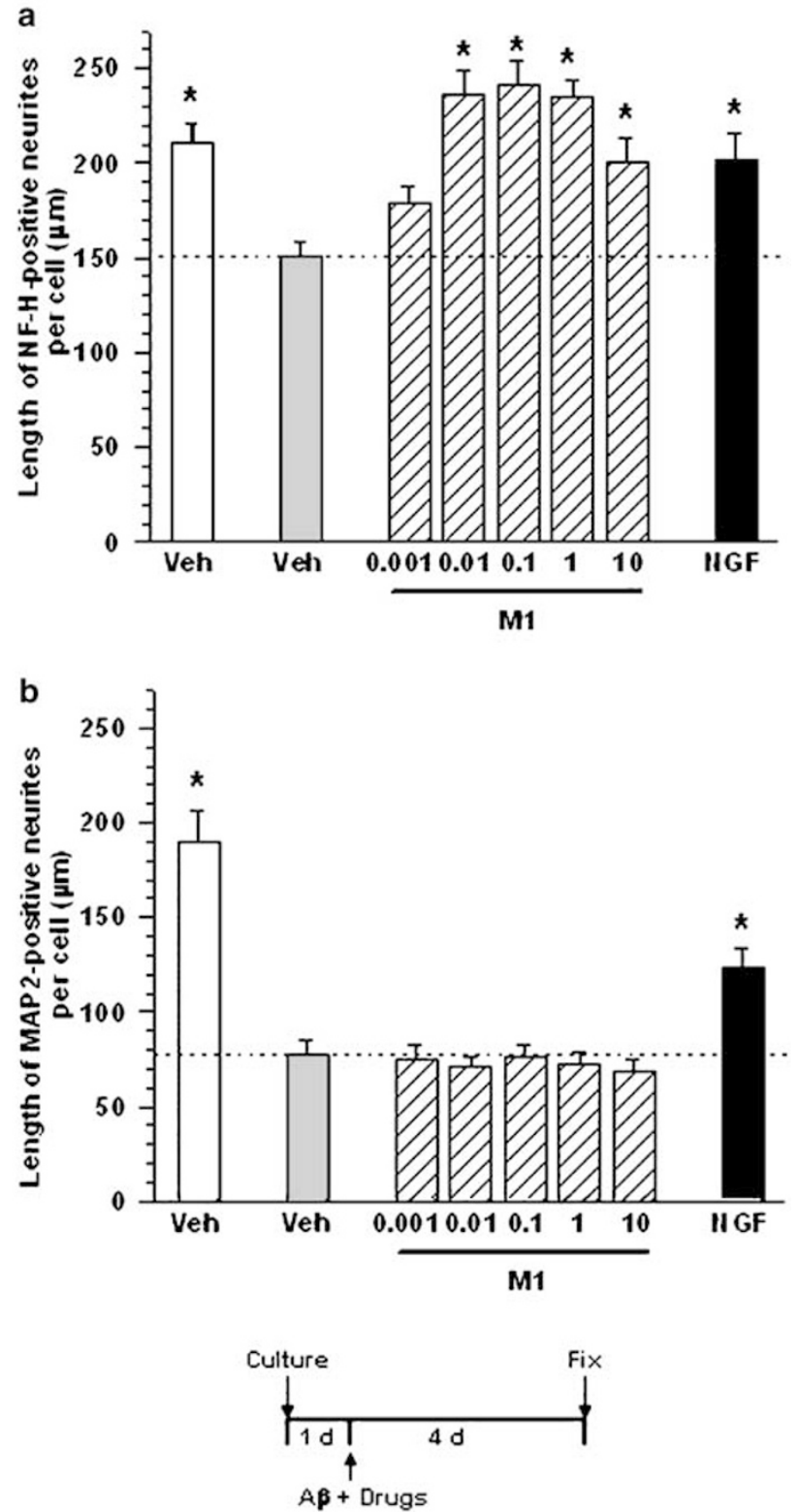

Figure 5 Effect of $\mathrm{MI}$ on $\mathrm{A} \beta(25-35)$-induced atrophy of axons and dendrites. MI (0.00I-I0 $\mu \mathrm{M})$, NGF $(100 \mathrm{ng} / \mathrm{ml})$, or vehicle (Veh, DMSO) was added to rat cortical neurons simultaneously with $10 \mu \mathrm{M} A \beta(25-35)$ । day after the start of the culture period. After 4 days, cells were fixed and immunostained for phosphorylated NF-H (a) and MAP2 (b). The lengths of neurites positive for phosphorylated NF-H or MAP2 per cell were measured. Values represent the means and SEM of 30 neurons. ${ }^{*} p<0.05$ when compared with the $A \beta(25-35)$ plus vehicle-treated group.

$\mathrm{A} \beta$ (25-35)-injected mice with degenerated axons and synapses, and that M1 exhibits axon-specific extension activity in rat cortical neurons.

In vivo study demonstrated that chronic p.o. treatment with ginsenoside $R b_{1}$ and $M 1$ drastically recovered the decreases in axonal density and synaptophysin expression levels in the cerebral cortex and the hippocampus, and that these treatments also ameliorated the memory disorder in A $\beta$ (25-35)-injected mice. The reduction of phosphorylated NF-H and synaptophysin levels by $\mathrm{A} \beta(25-35)$ was not obvious in the other areas of the brain. Maintained retention of spatial memory was also seen after a discontinuation of ginsenoside $\mathrm{Rb}_{1}$ and $\mathrm{M} 1$ administration. These results suggest that ginsenoside $R b_{1}$ and $M 1$ may induce the structural repair of neuronal connections.

When taken orally, the amount of intact ginsenoside $R b_{1}$ in the small and the large intestines is as low as $4.5 \%$ (Odani et $a l, 1983)$. In rat large intestine, ginsenoside $R b_{1}$ is completely metabolized to $\mathrm{M} 1$ at $3 \mathrm{~h}$ after administration (Karikura et al, 1991). Also in case of mice, only M1 is continuously detected in blood from $30 \mathrm{~min}$ to $16 \mathrm{~h}$ after oral administration of ginsenoside $\mathrm{Rb}_{1}$ (Hasegawa et al, 1997). In humans, M1 is detected in the plasma from $7 \mathrm{~h}$ after the intake of Ginseng, and in urine from $12 \mathrm{~h}$ after the intake, and an aglycone is not detected both in the plasma and urine (Tawab et al, 2003). These results suggest that M1 is the final metabolite of ppd-type saponins. The potencies of recoveries in $\mathrm{A} \beta(25-35)$-injected mice by p.o.-administered ginsenoside $\mathrm{Rb}_{1}$ and $\mathrm{M} 1$ were almost the same in the present results, indicating that most of the ginsenoside $R b_{1}$ orally administered was metabolized to M1. Considering that most of the ppd-type saponins are metabolized to M1, which is an active principal, the total content of ppd-type saponins is possibly an important index for the anti-AD activities of Ginseng drugs.

Donepezil is the drug most commonly used to treat AD patients in clinics. However, 6 days after discontinuation of donepezil administration, the repair effect on memory retention tests was weaker than by ginsenoside $\mathrm{Rb}_{1}$ or $\mathrm{M} 1$. In addition, axonal atrophy and synaptic loss were not ameliorated by donepezil. The dose of donepezil in the present experiment $(0.5 \mathrm{mg} / \mathrm{kg})$ was chosen as an effective dose in scopolamine-induced cognitive deficit in rats (Ogura et al, 2000). Clinical (Rogers et al, 1998) and basic research data (Ogura et al, 2000) have already shown that donepezil can reduce the rate of $\mathrm{AD}$ progression for approximately 1 year, but that it cannot ameliorate the core impairment, that is, the degeneration of neuronal circuits. The present results obtained with donepezil also indicate a limitation of acetylcholinesterase inhibitors with regard to therapeutic usefulness for $\mathrm{AD}$ patients.

In cell culture studies, axonal extension effects exerted by M1 were seen in not only normal neurons but also damaged neurons induced by $\mathrm{A} \beta(25-35)$. The effect of M1 on axonspecific formation corresponded with a result of mouse brains shown in Figures $3 \mathrm{~b}$ and $\mathrm{d}$. Axonal extension by M1 was lower after treatment with $\mathrm{A} \beta(25-35)$ rather than with simultaneous treatment, possibly because neuronal damage had already progressed and the number of neurons with neurite-re-extension ability seemed to be decreased when drugs were given after $\mathrm{A} \beta(25-35)$ administration. Regardless, $78.5 \%$ recovery of axonal length is indicative of the potent effects of M1. Neuritic atrophy by $\mathrm{A} \beta(1-40)$ and $\mathrm{A} \beta(25-35)$ has been reported in chick sympathetic neurons (Postuma et al, 2000) and rat cortical neurons (Grace et al, 2002). As neurite atrophy is thought to be due to unusual cell adhesion (Postuma et al, 2000; Grace and Busciglio, 2003), M1 may be capable of normalizing the adhesive mechanism. Although $\mathrm{A} \beta$ is known to cause neuronal death through an increase in $\left[\mathrm{Ca}^{2+}\right]_{\mathrm{i}}$ in neurons (Lin et al, 2001), an increase in peroxynitrites in microglias (Xie et al, 2002), and mitochondrial dysfunction in neurons (Casley et al, 2002), the death pathway has been shown to be mediated by 
a

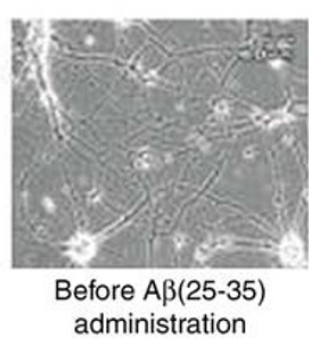

b

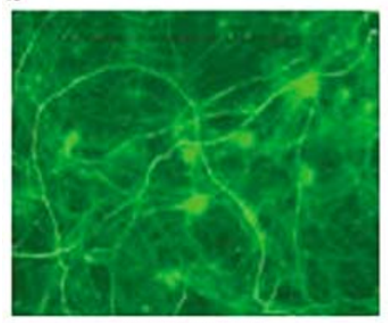

Saline / Veh

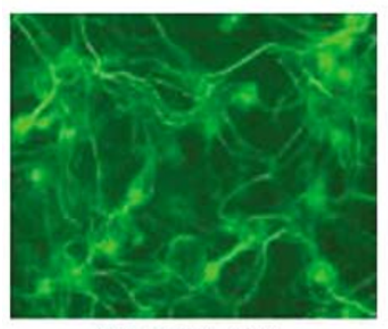

$A \beta(25-35) / M 1$

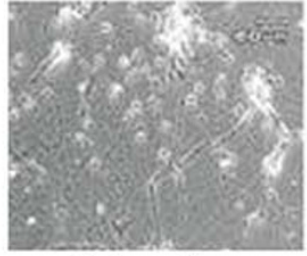

3 days after $A \beta(25-35)$ administration

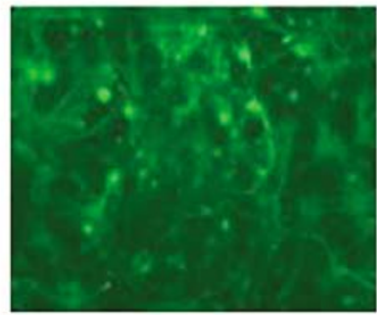

$A \beta(25-35) /$ Veh

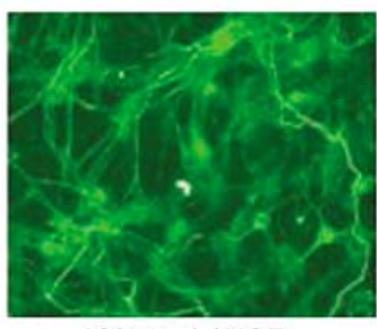

$\mathrm{A} \beta(25-35) / \mathrm{NGF}$

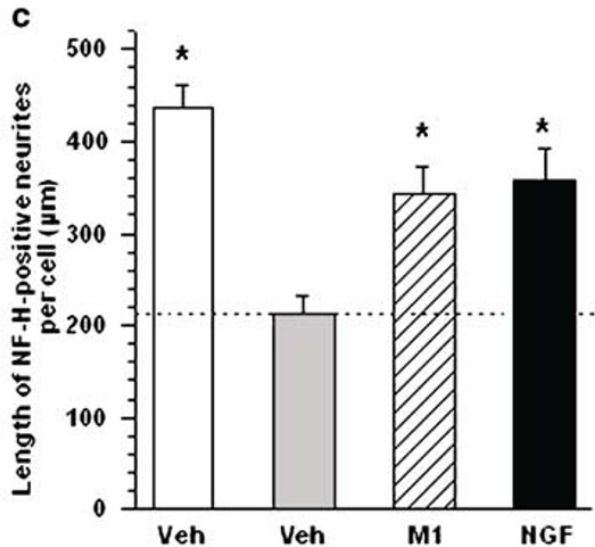

d
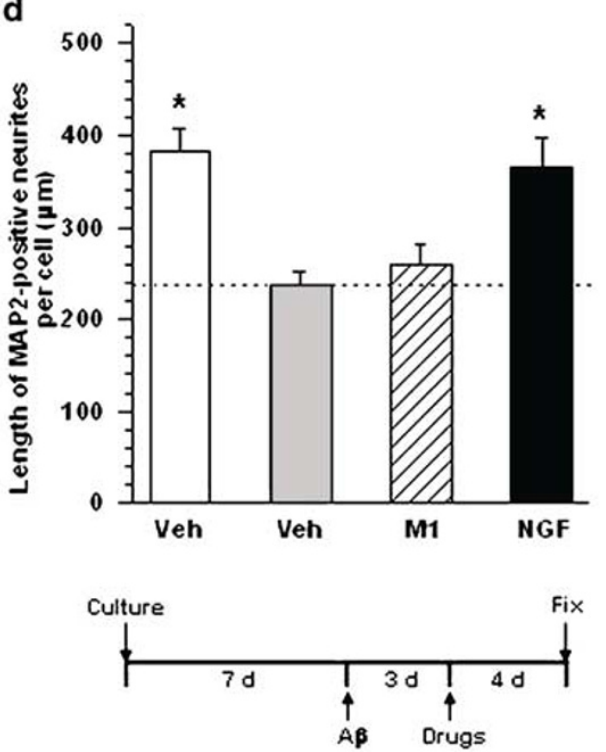

Figure 6 Effect of post-treatment with $\mathrm{MI}$ on $\mathrm{A} \beta(25-35)$-induced atrophy of axons and dendrites. $\mathrm{A} \beta(25-35)(\mathrm{I} 0 \mu \mathrm{M})$ was added to rat cortical neurons at 7 days in vitro. After 3 days, medium was replaced by a new one containing MI (0.0I $\mu \mathrm{M}), \mathrm{NGF}(\mathrm{I} 00 \mathrm{ng} / \mathrm{ml})$, or vehicle (Veh, DMSO). After 4 days, cells were fixed and immunostained for phosphorylated NF-H (b, c) and MAP2 (d). (a) Phase-contrast images of neurons before (left) and 3 days after (right) treatment with $A \beta(25-35)$ are shown. The lengths of neurites positive for phosphorylated NF-H or MAP2 per cell were measured. Values represent the means and SEM of 30 neurons. ${ }^{*} p<0.05$ when compared with the $A \beta(25-35)$ plus vehicle-treated group. Scale $=60 \mu \mathrm{m}(\mathrm{a})$, scale $=100 \mu \mathrm{m}(\mathrm{b})$.

separate molecular mechanisms of a neuritic dystrophy event (Postuma et al, 2000; Grace et al, 2002; Grace and Busciglio, 2003). Since ginsenoside $\mathrm{Rb}_{1}$ did not inhibit neuronal death induced by $\mathrm{A} \beta(25-35)$ (data not shown), the mechanism of rescuing axonal atrophy may not be the same as the one for recovery from $\mathrm{A} \beta$-induced neuronal death.

NGF extended both axons and dendrites, as shown in Figures 4-6. However, NGF itself is not expected to act as an antidementia agent because it is not able to pass through the blood-brain barrier, and, in fact, NGF has not shown significant efficacy in clinical trials for AD. In contrast, lowmolecular-weight substances that mimic the NGF effects and can pass through the blood-brain barrier, including AIT-082 (Rathbone et al, 1999) and cerebrolysin (Valouskova and Gschanes, 1999), have been tested in clinical trials for $\mathrm{AD}$ instead of NGF, although their reaction mechanisms have not yet been clarified. As M1 specifically enhances the outgrowth of axons, its signal pathway seems to be different from that of NGF. It is known that adrenergic (Chan-Palay, 1991) and GABAergic (Hardy et al, 1987) neurons as well as cholinergic neurons are also degenerated as $\mathrm{AD}$ progresses.
As such, drugs with NGF-independent effects may be needed to activate various populations of damaged neurons in the AD brain.

Memory dysfunction in the human brain with dementia is linked to synaptic loss (Geddes et al, 1986) and neuritic dystrophy (Grace et al, 2002). A reduction of the synaptic density has already been confirmed in both patients with AD (DeKosky and Scheff, 1990; Heinonen et al, 1995) and in transgenic mice overexpressing $\mathrm{V} 717 \mathrm{~F} \beta$-amyloid precursor protein (APP) (Games et al, 1995). However, the synaptic density has not been unequivocally determined in $\mathrm{A} \beta(25-$ $35)$ or $\mathrm{A} \beta(1-40)$-injected animals. In the present mouse model, synaptic loss was clearly observed, and complete recovery was also shown in the ginsenoside $\mathrm{Rb}_{1}$ - and $\mathrm{M} 1$ treated mice. Moreover, neither $\mathrm{A} \beta$ deposition nor neuronal death was seen at any sites in the $\mathrm{A} \beta(25-35)$-injected mouse brain. We previously used the reverse sequence of $\mathrm{A} \beta(25-$ 35 ), that is $\mathrm{A} \beta(35-25)$ as a negative control (Tohda et al, 2003). No memory impairment and synaptic loss were seen in $\mathrm{A} \beta(35-25)$-injected group, same as in saline-injected mice. Recently, evidences have accumulated suggesting that 
$\mathrm{A} \beta$ protein deposition is not necessarily a cause of synaptic loss. Oligomers of $\mathrm{A} \beta$, and not monomers or fibrils, are primarily involved in the inhibition of in vivo LTP in rats (Walsh et al, 2002) and in the memory dysfunction of APPtransgenic mice Tg2576 (Kotilinek et al, 2002). Spontaneous excitatory postsynaptic currents in cultured hippocampal neurons have been found to be reduced in the $A \beta(1-40)$ and $\mathrm{A} \beta(1-42)$ groups only $12 \mathrm{~h}$ after treatment (Ikegaya et al, 2002). These findings suggest that synaptic loss begins at a relatively early phase in $\mathrm{AD}$ patients, and that high fibrilization of $\mathrm{A} \beta$ does not appear to be critical to memory loss (Yamada and Nabeshima, 2000). Although brain atrophy caused by neuronal death has been observed in $\mathrm{AD}$ patients, neuronal death has not been seen in rodent $\mathrm{AD}$ models, even in double-transgenic (APP + PS) mice, which show progressive $\mathrm{A} \beta$ deposition (Gordon et al, 2002). We have repeatedly used the $\mathrm{A} \beta(25-35)$-injected model, and neuronal death has never been observed in mice showing memory impairment. In the progression of $\mathrm{AD}$, synaptic loss rather than $\mathrm{A} \beta$ deposition and/or neuronal death may be the most crucial phenomenon in terms of the pathophysiology of memory impairment. In triple transgenic mouse harboring PS1M146V, APPswe, and tau $\mathrm{P}_{\mathrm{P} 01 \mathrm{~L}}$ transgenes, synaptic dysfunction was seen before amyloid plaque and neurofibrillary tangle pathology (Oddo et al, 2003).

The present findings indicate that M1, a metabolite from ppd-type saponins by intestinal bacteria can produce a significant recovery from memory impairment, axonal atrophy, and synaptic loss in mice. The effect of M1 on axonal reconstruction was more confirmed in cultured cortical neurons. These results suggest that ppd-type saponins potentially ameliorate dementia by reconstructing the neuronal network when taken orally.

\section{ACKNOWLEDGEMENTS}

This work was supported by Kampou Science Foundation, Uehara Memorial Foundation, a Grant-in-Aid for Scientific Research (B), No. 11695086 in 1999-2001 from the Japan Society for the Promotion of Science, and a Grant-in-Aid for the 21st Century COE Program from the Ministry of Education, Culture, Sports, Science and Technology, Japan.

\section{REFERENCES}

Casley CS, Land JM, Sharpe MA, Clark JB, Duchen MR, Canevari L (2002). Amyloid fragment 25-35 causes mitochondrial dysfunction in primary cortical neurons. Neurobiol Dis 10: 258-267.

Chan-Palay V (1991). Alterations in the locus coeruleus in dementias of Alzheimer's and Parkinson's disease. Prog Brain Res 88: 625-630.

DeKosky ST, Scheff SW (1990). Synapse loss in frontal cortex biopsies in Alzheimer's disease: correlation with cognitive severity. Ann Neurol 27: 457-464.

Games D, Adams D, Alessandrini R, Barbour R, Berthelette P, Blackwell C et al (1995). Alzheimer-type neuropathology in transgenic mice overexpressing V717F $\beta$-amyloid precursor protein. Nature 373: 523-527.

Geddes JW, Anderson KJ, Cotman CW (1986). Senile plaques as aberrant sprout-stimulating structures. Exp Neurol 94: 767-776. Gordon MN, Holcomb LA, Jantzen PT, DiCarlo G, Wilcock D, Boyett KW et al (2002). Time course of the development of
Alzheimer-like pathology in the doubly transgenic PS1+APP mouse. Exp Neurol 173: 183-195.

Grace EA, Busciglio J (2003). Aberrant activation of focal adhesion proteins mediates fibrillar amyloid $\beta$-induced neuronal dystrophy. J Neurosci 23: 493-502.

Grace EA, Rabiner CA, Busciglio J (2002). Characterization of neuronal dystrophy induced by fibrillar amyloid beta: implications for Alzheimer's disease. J Neurosci 114: 265-273.

Hardy J, Cowburn R, Barton A, Reynolds G, Dodd P, Wester P et al (1987). A disorder of cortical GABAergic innervation in Alzheimer's disease. Neurosci Lett 73: 192-196.

Hasegawa H, Sung J-H, Benno Y (1997). Role of human intestinal Prevotella oris in hydrolyzing Ginseng saponins. Planta Med 63: 436-440.

Heinonen O, Soininen H, Sorvari H, Kosunen O, Paljarvi L, Koivisto E et al (1995). Loss of synaptophysin-like immunoreactivity in the hippocampal formation is an early phenomenon in Alzheimer's disease. Neuroscience 64: 375-384.

Ikegaya Y, Matsuura S, Ueno S, Baba A, Yamada MK, Nishiyama N et al (2002). Amyloid enhances glial glutamate uptake activity and attenuates synaptic efficacy. J Biol Chem 277: 32180-32186.

Karikura M, Miyase T, Tanizawa H, Taniyama T, Takino Y (1991). Studies on absorption, excretion and metabolism of Ginseng saponons. VII. Comparison of the decomposition of ginsenoside- $R \mathrm{~b}_{1}$ and $-\mathrm{Rb}_{2}$ in the digestive tract of rats. Chem Pharm Bull 39: 2357-2361.

Kotilinek LA, Bacskai B, Westerman M, Kawarabayashi T, Younkin L, Hyman BT et al (2002). Reversible memory loss in a mouse transgenic model of Alzheimer's disease. J Neurosci 22: 6331-6335.

Lin $\mathrm{H}$, Bhatia $\mathrm{R}$, Lal $\mathrm{R}$ (2001). Amyloid $\beta$ protein forms ion channels: implications for Alzheimer's disease pathophysiology. FASEB J 15: 2433-2444.

Mook-Jung I, Hong HS, Boo JH, Lee KH, Yun SH, Cheong MY et al (2001). Ginsenoside $\mathrm{Rb}_{1}$ and $\mathrm{Rg}_{1}$ improve spatial learning and increase hippocampal synaptophysin level in mice. J Neurosci Res 63: 509-515.

Nishiyama N, Cho SI, Kitagawa I, Saito H (1994). Malonylginsenoside $R b_{1}$ potetiated nerve growth factor (NGF)-induced neurite outgrowth of cultured chick embryonic dorsal root ganglia. Biol Pharm Bull 17: 509-513.

Odani T, Tanizawa H, Takino Y (1983). Studies on the absorption, distribution, excretion and metabolism of ginseng saponins. III. The absorption, distribution and excretion of ginsenoside $\mathrm{Rb}_{1}$ in the rat. Chem Pharm Bull 31: 1059-1066.

Oddo S, Caccamo A, Shepherd JD, Murphy MP, Golde TE, Kayed R et al (2003). Triple-transgenic model of Alzheimer's disease with plaques and tangles: intracellular $\mathrm{A} \beta$ and synaptic dysfunction. Neuron 39: 409-421.

Ogura H, Kosasa T, Kuriya Y, Yamanishi Y (2000). Donepezil, a centrally acting acetylcholinesterase inhibitor, alleviates learning deficits in hypocholinergic models in rats. Methods Find Exp Clin Pharmacol 22: 89-95.

Postuma RB, He W, Nunan J, Beyreuther K, Masters CL, Barrow CJ et al (2000). Substrate-bound beta-amyloid peptides inhibit cell adhesion and neurite outgrowth in primary neuronal cultures. J Neurochem 74: 1122-1130.

Rathbone MP, Middlemiss PJ, Gysbers JW, Andrew C, Herman MA, Reed JK et al (1999). Trophic effects of purines in neurons and glial cells. Prog Neurobiol 59: 663-690.

Rogers SL, Farlow MR, Doody RS, Mohs R, Friedhoff LT (1998). A 24-week, double-blind, placebo-controlled trial of donepezil in patients with Alzheimer's disease. Donepezil Study Group. Neurology 50: 136-145.

Saito H, Suda K, Schwab M, Thoenen H (1977). Potentiation of the NGF-mediated nerve fiber outgrowth by ginsenoside $R b_{1}$ in organ cultures of chicken dorsal root ganglia. Jpn J Pharmacol 27: $445-451$. 
Sugaya A, Yuzurihara M, Tsuda T, Yasuda K, Kajiwara K, Sugaya E (1988). Proliferative effect of ginseng saponin on neurite extension of primary cultured neurons of the rat cerebral cortex. J Ethnopharmacol 22: 173-181.

Tawab MA, Bahr U, Karas M, Wurglics M, Schubert-Zsilavecz M (2003). Degeneration of ginsenosides in humans after oral administration. Drug Metab Dispos 31: 1065-1071.

Tohda C, Matsumoto N, Zou K, Meselhy RM, Komatsu K (2002). Axonal and dendritic extension by protopanaxadiol-type saponins from Ginseng drugs in SK-N-SH cells. Jpn J Pharmacol 90: 254-262.

Tohda C, Tamura T, Komatsu K (2003). Repair of amyloid $\beta(25-$ 35)-induced memory impairment and synaptic loss by a Kampo formula, Zokumei-to. Brain Res 990: 141-147.

Valouskova V, Gschanes A (1999). Effects of NGF, b-FGF, and cerebrolysin on water maze performance and on motor activity of rats: short- and long-term study. Neurobiol Learn Mem 71: 132-149.

Walsh DM, Klyubin I, Fadeeva JV, Cullen WK, Anwyl R, Wolfe MS et al (2002). Naturally secreted oligomers of amyloid $\beta$ protein potently inhibit hippocampal long-term potentiation in vivo. Nature 416: 535-539.

Xie Z, Wei M, Morgan TE, Fabrizio P, Han D, Finch CE et al (2002). Peroxynitrite mediates neurotoxicity of amyloid $\beta$-peptide 1-42 and lipopolysaccharide-activated microglia. J Neuro Sci 22: 3484-3492.

Yamada K, Nabeshima T (2000). Animal models of Alzheimer's disease and evaluation of anti-dementia drugs. Pharmacol Ther 88: 93-113.

Zhao R, McDaniel WF (1998). Ginseng improves strategic learning by normal and brain-damaged rats. Neuroreport 9: $1618-1624$.

Zhong YM, Nishijo H, Uwano T, Tamura R, Kawanishi K, Ono T (2000). Red ginseng ameliorated place navigation deficits in young rats with hippocampal lesions and aged rats. Physiol Behav 69: 511-525. 